\title{
Interest Rate Pass-Through: Empirical Study Towards Monetary Policy Transmission Effectiveness in Indonesia
}

\author{
Heni Hasanah ${ }^{1 *}$ \\ ${ }^{1}$ Bogor Agricultural University, Bogor, Indonesia
}

\begin{abstract}
This research aims to measure the effectiveness of monetary policy transmission, especially through the interest rate channel. The analysis was conducted on the first stage of its transmission, namely Interest Rate Pass-through (IRPT). IRPT refers to condition in which retail interest rate (both deposit and lending rate) responds to changes in policy rate of central bank. IRPT was measured using Error Correction Model (ECM) for time series data in the period of January 2010 December 2015. The results of this study indicated that degree of long term and short term IRPT is incomplete for deposit and lending rate. In addition, IRPT for deposit rate is higher than lending rate, but the adjustment process of lending rate faster than deposit rate. Finally, model that include other variables (macroeconomic and internal banking indicator) generate long term IRPT which is smaller than the standard model. This results implies that the Central Bank, the FSA, and government needs to pay attention to the stability of the other variables that may interfere or reduce the effectiveness of monetary policy through the interest channel.
\end{abstract}

JEL Classification: E42, E43, E52

Keywords: Deposit rate, ECM, IRPT, Lending Rate, Policy Rate

\section{INTRODUCTION}

The ultimate goal of monetary policy is to maintain currency stability, one of which is reflected in the low and stable rate of inflation. To achieve this objective, Bank Indonesia sets the Bank Indonesia rate (BI rate) as the main policy instrument to influence the economic activities. The mechanism of how the change in BI rate affect inflation is often referred to the monetary policy transmission mechanism. This mechanism illustrates the actions of Bank Indonesia through changes in monetary instruments and operational targets affecting various economic and financial variables before finally affecting the ultimate goal of inflation.

The degree of interest pass-through that became the first stage of monetary policy effectiveness has been the concern of researchers around the world. This is reasonable given that the interest rate pass-through (IRPT) measures the degree to which a central bank's policy rate is responded by changes in bank's retail interest

* Corresponding author. Email address: $\quad$ henihasanah@ipb.ac.id
heni.hasanah.ipb@gmail.com 
rates both deposit and lending rates. The higher the degree of pass-through, the more effective the initial stages of the monetary policy transmission will be.

Basically, the underlying theory of pass-through degrees is the marginal cost theory. The theory was introduced by Rousseas in 1985. If the assumptions on perfectly competitive market structure are met, then the marginal cost is reflected in the price, so that the first derivative of the price against the marginal cost is one (complete pass-through). Of course if the assumption can not be fulfilled then the value of the derivative can be less than one (incomplete pass-through) or more than one.

Egert, et al. (2007) explains that the IRPT can be decomposed into two stages. The first stage measures how changes in policy rates are transmitted to both short- and long-term money market rates. This interbank call money rate is an operational target of monetary policy. While the second stage measures how changes in money market rates affect deposit and lending rates. Macroeconomic conditions are also considered to affect the degree of IRPT. During periods of high growth, banks can adjust interest rates quickly. Conversely, if the inflation rate is more volatile, it will weaken the IRPT degree considering the bank will wait longer before changing the interest rate.

Bredin, et al. (2001) explains that pass-through refers to the extent to which changes in money market rates are reflected in changes in retail interest rates in both the short and long term. Complete pass-through rates occur when movements in the money market rate lead to one for one movements in changes in retail interest rates. Bredin, et al. (2001) also stated that the degree of IRPT is generally influenced by several factors, such as the degree of bank competition, borrower characteristics, and cyclical elements.

The degree of adjustment of the retail interest rate also depends on how the bank defines the central bank policy changes as a temporary or permanent policy. If the monetary policy is temporary, the bank will wait to adjust its interest rate. Another factor is the bank's perception of whether the central bank's policy has been expected or not. Banks may respond slowly when they consider monetary policy to be temporary. The difficulties will also increase with the adjustment costs associated with changes in retail interest rates. The degree of bank competition may also affect the degree of IRPT. Higher bank competition will lead to higher passthrough degrees, such as those obtained from Kot (2004) research. This is because to survive in the competition, the bank must immediately respond to the slightest change in policy rate.

According to Durán-Víquez and Esquivel-Monge (2008), asymmetric information also affects the degree of IRPT as it would be an element of cost in the bank's cost structure. Some other researchers also add that the maturity level of each type of interest rate also affects the degree of IRPT. The faster the maturity, the greater the degree of pass-through. Finally, the degree of IRPT is also determined by the type of policy rate change itself, whether it has increased or decreased. Some studies have found a difference in the degree of pass-through when policy rates increase. Deposit interest rates are more sluggish when policy rates rise and lending rates are more sluggish when policy rates fall.

Many IRPT-related studies have been conducted such as Bredin et al. (2001), Espinosa-Vega and Rebucci (2003), Tieman (2004), Qayyum, et al. (2005), Durán-Víquez and Esquivel-Monge (2008), Maskay and Pandit (2009), Ozdemir (2009), Egert, et al. (2007), Kwapil and Scharler (2006), Sorensen and Werner 
(2006), Marotta (2008), Rehman (2009), Samba and Yan (2010), Kot (2004) and Kobayashi (2008). There are two main approaches used in previous studies to calculate the degree of IRPT. First, using cointegration approach and ECM model. While the second using cointegration approach with ARDL method. So far there has been no conclusive results that mention which method is better to analyze the degree of IRPT. Another approach used is the non-linear asymmetric VECM to see asymmetric effects such as those performed by Aydin (2007). Meanwhile, Avci and Yucel (2016) use another method of Interacted Panel VAR (IPVAR).

Major findings from the results of these studies are the incomplete passthrough for bank retail interest rates (see Tang, et al., 2015, Samba and Yan, 2010, Kobayashi, 2008, Bredin, et al., 2001, Espinosa-Vega and Rebucci, 2003, and Sorensen and Werner, 2006). While other studies have found a complete passthrough especially in the long term, among others, Qayyum, et al. (2005), DuránVíquez and Esquivel-Monge (2008), and Ozdemir (2009). But Marotta (2008) finds a near-complete pass-through in the EMU and Greek. Associated with asymmetric responses to changes in policy rates, Durán-Víquez and EsquivelMonge (2008) found no asymmetry occurring for cases in Costa Rica. On the contrary, Tang, et al. (2015) found an asymmetric effect in the degree of IRPT in Malaysia and Muhtaseb (2017) in Lebanon.

There have also been several IRPT-related studies comparing IRPT for specific areas, which are more common in the euro area. Egert, et al. (2007), examines IRPT for Central and Eastern Country (CEE) with results showing that IRPT values continue to decline over time and are expected to continue declining in the future. Next, Kwapil and Scharler (2006) compare the IRPT process in the euro area with America. The findings show that on average, the long-term IRPT in the euro area is lower than the American IRPT. While Sorensen and Werner (2006) find great heterogeneity in the Euro area related to long-term pass-through equilibrium and its speed of adjustment.

For Indonesia, Rehman (2009) analyzed IRPT for five ASEAN countries using the cointegration and ECM approach. The results show that Indonesia and the Philippines have the most effective interest rate transmission mechanism followed by Thailand, Singapore and Malaysia. Feriansyah (2015) found that the long-term pass-through coefficient for deposit rates is greater than the lending rate for the majority of regions in the world including Indonesia. Recent studies by Wibowo and Lazuardi (2016) conclude that the adjustment of bank retail interest rate in Indonesia takes a long time.

Engle Granger cointegration and ECM are still used in this study as the majority of IRPT studies use this approach, with a stepwise regression method. This study has some differences with previous studies, especially for the focus of study in Indonesia. First, this study uses the Interbank Money Market (PUAB) rate as a proxy of policy rate. As previous explanation, Egert, et al. (2007) states that the policy rate which directly affects the retail interest rate is the money market interest rate as the operational target of monetary policy. Some previous studies in Indonesia still use the BI rate as a proxy of the policy rate itself. There is a study of Bank Indonesia which has been using PUAB as policy rate (Kusmiarso, et al., 2002). Second, this study includes another variable as control variable of macroeconomy variable that is inflation and internal variable of banking performance such as Return on Asset (ROA) or Return on Equity (ROE) and 
Operational Cost to Operating Revenue Ratio (BOPO) follow Egert, et al. (2007), Sorensen and Werner (2006), and Avci and Yucel (2016), which have not been found in previous studies for the Indonesian case. ROA is a profitability proxy where IRPT is predicted to decrease if ROA increases (Sorensen and Werner, 2006). BOPO is used as an indicator of bank efficiency. If BOPO gets higher then expected IRPT value is increasing. So the research is expected to fill that gaps as some of novelty.

\section{DATA AND METHOD}

The data used in this study are all secondary data in monthly frequency. The period of the study was conducted from January 2010 to December 2015. Purposively, the taking of the period considered that the effect of the 2008 financial crisis to have weakened in 2010 . The year 2015 becomes the final period of the research data because it is the last year before the enactment of new interest rate policy namely BI 7-day Repo Rate in 2016. The data used are obtained from the publication of the Financial Services Authority (OJK) and Bank Indonesia.

The research on policy rate pass-through was analyzed by using the standard cointegration approach with Engle-Granger Method (1987). Engle and Granger (1987) states that a linear combination of two or more variables may be stationary I (0), although the variables individually are not stationary I (1). If this linear combination is stationary then the linear relationship can be referred to as cointegration and if its form is an equation then this is a cointegration equation and its parameters are cointegration parameters reflecting long-term relationships.

The Engle-Granger cointegration testing method actually uses the Augmented Dickey-Fuller (ADF) method in two stages. In the first stage, the variables (in levels) are tested independently with the ADF method, and generally the non-stationary variables will be obtained. The second stage, the dependent variable is regressed with explanatory variables using OLS and then do the test of residual regression. Therefore, this method is also referred to as Augmented EngleGranger (AEG). Then if the residual is stationary at the level, then the variables can be modeled with Error Correction Model (ECM).

The pass-through problem in this study refers to the Egert model, et al. (2007) and Sorensen and Werner (2006). Here are the cointegration and ECM models that are estimated by finding optimal lag and stepwise regression. Stepwise regression is used to assure statistically that the addition of macro and internal variables of banking and its lag is useful in improving the model.

$$
\begin{aligned}
B R_{t}= & \alpha_{0}+\alpha_{1} P R_{t}+\alpha_{2} I N F_{t}+\alpha_{3} R O A_{t}+\alpha_{4} B O P O_{t}+e_{t} \\
\Delta B R_{t}= & \beta_{0}+\sum_{i=1}^{p} \beta_{i} \Delta B R_{t-i}+\sum_{j=0}^{p} \gamma_{j} \Delta P R_{t-j}+\sum_{k=0}^{p} \delta_{k} \Delta I N F_{t-k}+ \\
& \sum_{l=0}^{p} \theta_{l} \Delta R O A_{t-l}+\sum_{m=0}^{p} \vartheta_{m} \Delta B O P O_{t-m}+\varphi e_{t-1}+u_{t}
\end{aligned}
$$

where :

$B R_{t} \quad$ : Banking rate $(\%)$

$P R_{t} \quad:$ Policy rate (money market rate, PUAB) $(\%)$

$I N F_{t} \quad$ : Inflation (\%)

$R_{0} A_{t}:$ Return on Asset (\%)

$\mathrm{BOPO}_{t}$ : Operational Cost to Operating Revenue Ratio (\%) 


$$
\begin{array}{ll}
e_{t}, u_{t} & : \text { Error term } \\
\alpha_{1} & : \text { Long term IRPT coefficient } \\
\gamma_{0} & : \text { Short term IRPT coefficient } \\
\varphi & : \text { Adjustment coefficient }
\end{array}
$$

For comparison, the standard equation in which each banking rate is only influenced by the policy rate (without including other independent variables such as inflation, BOPO, and ROA) is also estimated in this study. The standard model is as follows.

$$
\begin{gathered}
B R_{t}=\alpha_{0}+\alpha_{1} P R_{t}+e_{t} \\
\Delta B R_{t}=\beta_{0}+\sum_{i=1}^{p} \beta_{i} \Delta B R_{t-i}+\sum_{j=0}^{p} \gamma_{j} \Delta P R_{t-j}+\varphi e_{t-1}+u_{t}
\end{gathered}
$$

\section{RESULTS AND DISCUSSION}

Figure 1 shows the movement of several interest rates. The interest rates are BI Rate, interbank money market (PUAB), investment lending rate (LR_INVESTMENT), working capital lending rate (LR_WORKCAP), 3-month deposit rate (DR_DEP3M) and 12-month deposit rate (DR_DEP12M). In general, the movement of PUAB is in line with the movement of BI rate, and movement of all interest rates in line with both BI rate and PUAB. Compared to the interbank money market, all interest rates are always above that, except for one point in August 2015 (3-month deposit rate is less than the interbank money market rate). Unlike the case when compared with BI rate. There are several periods for 3-month deposit rates that are smaller than the BI rate (see July-October 2012 and MarchNovember 2013). In line with what Egert, et al. (2007) stated that policy rate (BI rate) has no direct effect on banking retail interest rate although it is still a reference for bank. But technically the operational interest rate of money market in this case PUAB is more appropriate to be a reference as a marginal cost banking proxy. From the picture we can also seen that interbank rates (PUAB) appear to have a fairly wide difference with the BI rate as its anchor.

The Engle-Granger cointegration approach has data prerequisites. The data must be stationary (integrated) in the same order. Non-stationarity test of data has been done by ADF method where the test result shows all variables are stationary at first difference (Table 1). The second stage of estimation of cointegration equation (long term) is done to test the residual of the equation. If the long-term residual are stationary at its level, then there is cointegration. The results of cointegration testing (residual stationary test can be seen in Table 2) show that all residuals are stationary at significant levels. The estimation of model in equation 1 was done by stepwise regression, but the long-term equation in equation 3 was conducted by simple regression method. 


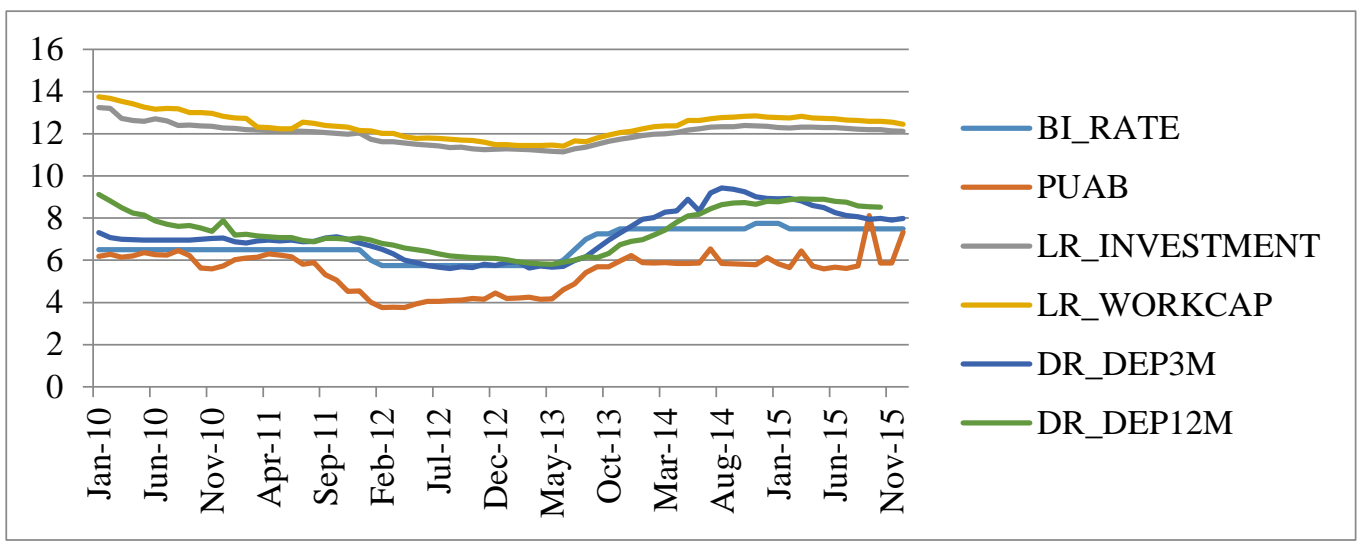

Figure 1 Policy Rates and Retail Rates Movement

The next stage is the estimation of ECM (short-term) model. To build the best model, stepwise regression is also used in this estimation to determine the best model both from the independent variable side and from the lag side of the exogenous variable. Stepwise regression is performed both for the ECM model in equation 2 and equation 4. Optimal lag determination is based on the principle of parsimony (simple) shown by several criteria, LR, FPE, AIC, SC, and HQ. Technically the optimal lag chosen is the smallest besides zero lag (Table 3 ).

Table 1 ADF Test Results for Variables

\begin{tabular}{lcc}
\hline \multicolumn{1}{c}{ Variable } & $\begin{array}{c}\text { ADF value } \\
\text { (in Level) }\end{array}$ & ADF value (in First Difference) \\
\hline PUAB & -0.1696 & $\mathbf{- 4 . 2 9 9 5}$ \\
DR_DEP3M & 0.2018 & $\mathbf{- 3 . 4 4 8 6}$ \\
DR_DEP12M & 0.2664 & $\mathbf{- 2 . 8 1 1 9}$ \\
LR_WORKCAP & -2.1406 & $\mathbf{- 2 . 7 3 2 7}$ \\
LR_INVESTMENT & -0.3432 & $\mathbf{- 5 . 8 5 9 6}$ \\
INFLATION & -2.8021 & $\mathbf{- 5 . 4 9 0 7}$ \\
BOPO & $\mathbf{- 4 . 7 7 2 0}$ & $\mathbf{- 7 . 2 2 7 5}$ \\
ROA & -2.6161 & $\mathbf{- 8 . 6 0 1 2}$ \\
\hline
\end{tabular}

Note: Bold indicates that the ADF value is less than the MacKinnon critical value at $5 \%$ 
Interest Rate Pass-Through: Empirical Study Towards Monetary Policy Transmission

Effectiveness in Indonesia

Table 2 ADF Test Results for Residual

\begin{tabular}{lccl}
\hline \multicolumn{1}{c}{ Interest Rate } & Equation & ADF Value & Keterangan \\
\hline 3-month Deposits & 1 & $\mathbf{- 2 . 1 2 7 7}$ & Cointegrated \\
& 3 & $\mathbf{- 2 . 3 0 3 2}$ & Cointegrated \\
12-month Deposits & 1 & $\mathbf{- 2 . 6 2 1 8}$ & Cointegrated \\
\multirow{3}{*}{ Working capital loan } & 3 & $\mathbf{- 2 . 7 8 4 2}$ & Cointegrated \\
& 1 & $\mathbf{- 2 . 7 0 2 0}$ & Cointegrated \\
Investment loan & 3 & $\mathbf{- 3 . 6 0 3 7}$ & Cointegrated \\
& 1 & $\mathbf{- 2 . 1 7 7 0}$ & Cointegrated \\
& 3 & $\mathbf{- 4 . 0 5 5 8}$ & Cointegrated \\
\hline
\end{tabular}

Note: Bold indicates that the ADF value is less than the MacKinnon critical value at $5 \%$

Table 3 Lag Optimum in ECM

\begin{tabular}{lcccccc}
\hline \multirow{2}{*}{ Interest Rate } & \multirow{2}{*}{ Equation } & \multicolumn{5}{c}{ Lag } \\
\cline { 3 - 7 } & & LR & FPE & AIC & SC & HQ \\
\hline 3-month Deposits & 2 & 3 & 3 & 3 & 2 & 3 \\
\multirow{3}{*}{ 12-month Deposits } & 4 & 2 & 2 & 2 & 0 & 0 \\
\multirow{3}{*}{ Working capital loan } & 2 & 2 & 2 & 2 & 2 & 2 \\
\multirow{3}{*}{ Investment loan } & 4 & 2 & 2 & 2 & 0 & 0 \\
& 2 & 3 & 3 & 3 & 0 & 3 \\
& 4 & 2 & 2 & 2 & 0 & 0 \\
& 2 & 5 & 5 & 5 & 1 & 3 \\
& 4 & 1 & 1 & 1 & 0 & 0 \\
\hline
\end{tabular}

Table 4 shows the comparison of IRPT using standard models (without including macro variables and internal banking variables) and modification models by adding other variables as control variables for deposit and lending rates. This comparison was done to find the difference in retail rates response to the interbank money market changes when other variables are included or not into the model. This is considered since the majority of previous studies did not include other variables as controls such as macroeconomic indicators and internal bank variables. Such control variables may affect the response rates of retail rates to changes in policy rates as stated by Egert, et al. (2007), Sorensen and Werner (2006), and Avci and Yucel (2016), which have not been found in previous studies for the Indonesian case. From Table 4 it can be seen that the transmission of the policy rate (the interbank money market rate) changes is incomplete pass-through for both lending and deposit rates. This result is in accordance with previous studies as described in the introduction. In other words, the interbank money market rate as the operational target of monetary policy is not fully responded by the banks. This indicates that the initial stage of monetary policy transmission has not been effective.

Some interesting results can be seen from Table 1. First, the long-term IRPT of deposit rates is higher than the IRPT of lending rates. This also confirmed the results of previous studies that found the similar thing e.g. Espinosa-Vega and Rebucci (2003) for Euro Area and Canada, and Feriansyah (2015). However, from adjustment time perspectives to achieve long-term equilibrium, lending or lending rates adjust faster than deposit rates. This happens because the length of adjustment considers the value of the adjustment coefficient. 
Table 4 Comparison for Each Type of Retail Interest Rate

\begin{tabular}{llcc}
\hline $\begin{array}{c}\text { Type of } \\
\text { Interest } \\
\text { Rate }\end{array}$ & \multicolumn{1}{c}{ Comparison } & $\begin{array}{c}\text { Modification Model } \\
\text { (Banking rate as a function } \\
\text { of PUAB, inflation, ROA, } \\
\text { adn BOPO) } \\
\text { Equation 1 and 2 }\end{array}$ & $\begin{array}{c}\text { Standard Model } \\
\text { (Banking rate as a } \\
\text { function of PUAB) } \\
\text { Equation 3 and 4 }\end{array}$ \\
\hline \multirow{2}{*}{ 3-month } & Long run IRPT & $0.69^{* * *}$ & $0.76^{* * *}$ \\
Deposits & Short run IRPT & 0.07 & 0.07 \\
& ECT coefficient & $-0.06^{*}$ & $-0.05^{*}$ \\
& Speed of adjustment & 15.5 months & 18.6 months \\
\hline \multirow{2}{*}{ 12-month } & Long run IRPT & $0.59^{* * *}$ & $0.74^{* * *}$ \\
Deposits & Short run IRPT & 0.03 & 0.02 \\
& ECT coefficient & -0.04 & $-0.06^{* *}$ \\
& Speed of adjustment & 24.3 months & 16.3 months \\
\hline \multirow{2}{*}{ Working } & Long run IRPT & $0.35^{* * *}$ & $0.38^{* * *}$ \\
capital loan & Short run IRPT & $0.04^{* *}$ & $0.03^{*}$ \\
& ECT coefficient & $-0.16^{* * *}$ & $-0.21^{* * *}$ \\
& Speed of adjustment & 6 months & 4.6 months \\
\hline \multirow{2}{*}{ Investment } & Long run IRPT & $0.40^{* * *}$ & $0.44^{* * *}$ \\
loan & Short run IRPT & 0.01 & 0.01 \\
& ECT coefficient & $-0.08^{* *}$ & $-0.13^{* * *}$ \\
& Speed of adjustment & 12.4 months & 7.6 months \\
\hline
\end{tabular}

Note: $* * *, * *, *$ respectively show that the coefficients are significant at $1 \%, 5 \%$, and $10 \%$.

The coefficient of adjustment of the 3-month deposit rate is -0.06, meaning that the change in policy rate is adjusted around six percent in the 3-month deposit rate change in the following month. Means that the adjustment process is just completed (100 percent) in the 16th month after the interbank money market changes. As for the investment lending rate, the change in policy rate (PUAB) adjusted around 16 percent in the change of interest rate on investment credit in the following month. In other words, the long-term adjustment process due to changes in PUAB is completed in the sixth month which implies that lending rates adjust more quickly. The faster time needed to adjust for lending interest rate than the deposit rate is in line with the results of Wibowo and Lazuardi (2016). So that, the results of this study indicate that the change in interbank money market is effectively responded by the deposit interest rate, but the adjustment process takes longer time. Conversely, the lending rates does not fully respond to changes in the interbank money market, but adjusts faster.

Second, IRPT of 12-months deposit is smaller than IRPT of 3-month deposit. Based on the maturity, other studies confirm this results (e.g. Liu, et al., 2008), that the degree of pass-through for short-term interest rates is greater than long-term interest rates. Third, the IRPT which obtained based on standard model estimation (ignoring the influence of other variables) tends to be larger than the modification model (including other variables as controls). This means that if the influence of other variables is ignored, the IRPT tends to get closer to the complete pass-through. However, the opposite result obtained if the other variables included in the model estimation. This implies that the level of effectiveness of monetary 
policy through changes in the interbank money market rate (PUAB) as operational targets is relatively decreased if other variables are considered to affect the banking retail interest rate.

Finally, the investment lending rates adjusts faster to return to its long-term equilibrium compared to working capital lending rates. But the degree of long term pass-through of investment lending rates is lower than the working capital lending rates. This result is in line with previous research from Wibowo and Lazuardi (2016) and Kusmiarso, et al. (2002). In terms of lending maturity, investment loan is a medium and long term credit. While working capital loan is a short-term credit with a maximum period of one year. On average, the working capital lending rate is higher than the investment lending rate. Moreover, the non performing loans (NPL) in working capital loan is generally higher than the investment loan. These are expected to be the reasons why investment lending rates respond more quickly to changes in interbank rates (PUAB). In the case of working capital lending rates, high NPL are likely to result in high risks, so changes in policy rates are slowly responded by that rates.

\section{CONCLUSION}

Monetary policy can be said to be effective if the instrument used by the Central Bank succeeds in influencing the ultimate goal e.g. inflation. This study analyzes interest rate pass-through as the initial stages of monetary policy transmission that measures the response of bank interest rates to changes in policy rates. The results of this study show several things, that is i) incomplete passthrough in both deposit and lending rates; ii) the degree of pass-through of deposit interest rate is higher than the lending rate, but the adjustment process of lending rates is faster; and iii) the inclusion of other independent variables as determinants of bank interest rates resulted in smaller IRPT coefficient. These results imply that monetary policy in the early stages can not yet be said to be effective and its effectiveness decreases when considering other variables such as macroeconomic indicators and internal variables of banks. Lastly, Bank Indonesia, OJK, and the government need to jointly maintain the stability of other variables that may alter or even reduce the effectiveness of monetary policy. Based on the findings, when the inflation, ROA, and BOPO variables are included as control variables that affect the retail rate changes, the degree of pass-through becomes decreased. This condition occurs consistently for all types of retail rates that are the scope of this study. This means that the effectiveness of monetary policy has decreased too. So that the inflation which is the main concern of Bank Indonesia and ROA, BOPO which become internal indicators of banks under the supervision of OJK need to be kept stable.

\section{References}

Avci S.B., \& Yucel, E. (2016). Effectiveness of Monetary Policy: Evidence from Turkey. MPRA Paper, 70848, 1-35.

Aydin, H.I. (2007). Interest Rate Pass-Through in Turkey. Working Paper No. 07/05, The Central Bank of the Republic of Turkey. 
Bredin, D., Fitzpatrick, T., \& Reilly, G.O. (2001). Retail Interest Rate PassThrough: The Irish Experience. Technical Paper, Central Bank of Ireland.

Durán-Víquez, R., \& Esquivel-Monge, M. (2008). Policy Rate Pass-Through : Evidence from The Costa Rican Economy. Research Paper, Banco Central de Costa Rica.

Egert, B., Crespo-Cuaresma, J., \& Reininger, T. (2007). Interest Rate PassThrough in Central and Eastern Europe: Reborn from Ashes Merely to Pass Away?. Journal of Policy Modeling, 29(2), 209-225.

Engle, R. F., \& Granger, C. W. J. (1987). Co-Integration and Error Correction: Representation, Estimation, and Testing. Econometrica, 55(2), 251-276.

Espinosa-Vega, M. A., \& Rebucci, A. (2003). Retail Bank Interest Rate PassThrough: Is Chile Atypical ?. Working Papers, Central Bank of Chile.

Feriansyah. (2015). Kajian Empiris Interest Rate Pass-Through Sebelum dan Sesudah Subprime Mortgage: Pengalaman 41 Negara di Dunia. [Skripsi]. Institut Pertanian Bogor.

Kobayashi, T. (2008). Incomplete Interest Rate Pass-Through and Optimal Monetary Policy. International Journal of Central Banking, 4(3), 77-118.

Kot, A. (2004). Is interest rate pass-through related to banking sector competitiveness?. Working Paper, National Bank of Poland.

Kusmiarso, B., Sukawati, E., Pambudi, S., Angkoro, D., Prasmuko, A., \& Hafidz, I. S. (2002). Interest rate Channel of Monetary Transmission in Indonesia. Dalam Warjiyo dan Agung (Ed). Transmission Mechanism of Monetary Policy in Indonesia. Bank Indonesia.

Kwapil, C., \& Scharler, J. (2006). Interest Rate Pass-Through, Monetary Policy Rules and Macroeconomic Stability. Working Paper, Oesterreichische Nationalbank.

Liu MH, Margaritis D, Tourani-Rad A. (2008). Monetary Policy Transparency and Pass-Through of Retail Interest Rates. Journal of Banking and Finance, 32(4), 501-511.

Marotta, G. (2008). Lending Interest Rate Pass-Through in The Euro Area : A Data-driven Tale. Working Paper No. 12, Centro Study Banca E Finanza.

Maskay, N. M., \& Pandit, R. (2009). Interest Rate Pass-Through in Nepal (An Examination over the Period of FY 1990:1 - FY 2009:4). Working Paper, Nepal Rastra Bank.

Muhtaseb, B. M. A. (2017). Interest Rate Pass-Through and Monetary Transmission in Lebanon Loan Market. International Journal of Business and Economics Research, 6(1), 1-6. 
Ozdemir, B. K. (2009). Retail Bank Interest Rate Pass-Through: The Turkish Experience. International Research Journal of Finance and Economics. Issue, 28, 7-15.

Qayyum, A., Khan, S., \& Khawaja, I. (2005). Interest Rate Pass-through in Pakistan: Evidence from Transfer Function Approach. The Pakistan Development Review, 44(4), 975-1001.

Rehman, H. (2009). Interest Rate Pass-Through and Banking Market Integration in ASEAN : A Cross Country Comparison [abstrak]. Faculty of Business and Accountancy, University of Malaya.

Samba, M. C., \& Yan, Y. (2010). Interest Rate Pass-through in the Central African Economic and Monetary Community (CAEMC) Area: Evidence from an ADRL Analysis. International Journal of Business and Management, 5(1), $31-41$.

Sorensen, C. K., \& Werner, T. (2006). Bank Interest Rate Pass-Through in The Euro Area A Cross Country Comparison. Working paper No. 580, European Central Bank.

Tang, M. M., Puah, C., \& Liew, V. K. (2015). The Interest Rate Pass-Through in Malaysia: An Analysis on Asimmetric Adjustment. International Journal of Economics and Management, 9(2), 370-381.

Tieman, A. (2004). Interest Rate Pass-Through in Romania and Other Central European Economies. Working Paper, International Monetary Fund.

Wibowo, B., Lazuardi, E. (2016). Uji Empiris Transmisi Kebijakan Moneter: Interest Rate Pass-through Sektor Perbankan Indonesia. Jurnal Ekonomi dan Pembangunan Indonesia, 16(2), 187-204. 